\title{
STUDENTS' AGGRESSIVENESS AND ITS CONNECTION WITH INTELLECTUAL DEVELOPMENT IN YOUTH
}

\author{
Larisa V. Lezhnina ${ }^{1 *}$, Irina A. Kurapova ${ }^{2}$ \\ 'Prof. Dr., Mari State University, RUSSIA, flouers@mail.ru \\ ${ }^{2}$ Assoc. Prof., Mari State University, RUSSIA, kurapova.psy@mail.ru \\ ${ }^{*}$ Corresponding Author
}

\begin{abstract}
The article is devoted to the study of the actual problem of the growth of students' aggressiveness in various forms of manifestations in schools and colleges. The subject of the research is the relationship of students' aggressiveness and the level of intellectual development in youth. The purpose of the research is an empirical study of forms of aggressive behavior in youth and verification of its relationship with the level of intellectual development of students in professional colleges.

The theoretical basis of the study is classical approaches to the understanding of aggressiveness and hostility as personality traits, manifested in destructive subjective-objective relationships or as a secretiveverbal reaction of negative feelings and assessments. A sample of the empirical study was college students: 94 boys and girls aged 15-17. The method of organizing the investigation is an ascertaining experiment. The empirical data collection was carried out using the method of "Buss-Durkee Hostility Inventory" (by A.H. Buss and A. Durkee) and "Short-form selection test" (by E.F. Wonderlic, adapted by V.N. Buzin).

The results obtained allowed us to identify the main forms of students' aggressiveness in youth, the levels of hostility and aggressiveness, as well as the general level of intellectual development of college students. An inverse correlation was established between the integral indicator of their mental development and physical aggression.
\end{abstract}

Keywords: Aggressiveness, college students, youth, hostility, intellectual development.

\section{INTRODUCTION}

Modern observations and research in many branches of human and social sciences indicate a significant increase in personality and behavioral disturbances in human development and vital activity over the past decades. For example, scientists of the Institute of Psychology of the Russian Academy of Sciences, when drawing up a portrait of a Russian at the beginning of the current decade, calculated that the aggressiveness of Russians tripled from 1981 to 2011 (Sejchas vzorvus', 2013). In this regard, the actualization of the problem of aggressive behavior of teenagers studying in schools, technical schools and colleges is not surprising, since the "diseases" of modern society are reflected in various social institutions, as in a mirror.

Russian psychologists, sociologists and educators notice in their studies that the proportion of school 
aggressors is from 9 to 20\% of students (Gusejnova \& Enikolopov, 2014; Enikolopov, 2010; Ivanjushina, Titkova \& Aleksandrov, 2016). According to foreign studies, the proportion of aggressors in European and American schools also varies from 4 to $20 \%$ (Juvonen \& Graham, 2014; Salmivalli, 2010).

The new tendency of the last decade is obvious: public aggression, initiated by the students themselves in educational organizations, as evidenced by the countless videos posted on social networks by the participants and students themselves. According to data from various sources, at least $60 \%$ of Russian schoolchildren face various types of direct or indirect aggression against them. Not only students, but also teachers suffer from such manifestations today: $70 \%$ of 2,800 teachers surveyed by Higher School of Economics researchers in 75 regions of Russia said they had experienced different forms of bullying (Rossijskie shkol'niki, 2018).

A particularly disturbing fact is the growth of aggressive acts initiated by teenagers and young people, with the use of firearms and with victims among peers, teachers, family members or casual passers-by. So, 2018 overtook five previous years in the number of victims of shooting in Russian schools and colleges (Sluchai napadenij, 2018). The last such resonant event was the shooting of group mates by a 19-year-old student at a college in Blagoveshchensk in November 2019.

Obviously, school aggression has become a new epidemic of our time. It actualizes the theoretical understanding of the problem of aggressive behavior of students in educational institutions and experimental study of the factors of their aggressiveness.

The subject of the research is the relationship of students' aggressiveness and the level of intellectual development in youth. The purpose of the research is an empirical study of forms of aggressive behavior in youth and verification of its relationship with the level of intellectual development of students in professional colleges.

\section{OVERVIEW}

The problem of aggressive behavior has long been in the research field of psychologists. Aggression and aggressiveness are comprehensively studied in foreign psychology: as a part of a behavioral approach (Buss, 1961), psychoanalytic approach (Freud, 1961; Lorenz, 1963), ethical-humanistic approach (Allport, 1960; Rogers, 1995), theories of social learning (Bandura, 1983), frustration theory (Berkowitz, 1993; Dollard, Miller, Doob, Mowrer \& Sears, 1939). Russian psychology describes in detail the types, features, forms of aggressiveness (Il'in, 2014; Nalchadzhan, 2007, Safonov, 2003), and factors of its development (Rean, 1996; Semenjuk, 1996; Sen'ko, 2002; Furmanov, 1996).

The modern approach to the study of aggressiveness is based on its understanding as a complex phenomenon that is forming and manifesting itself under the influence of a number of factors, such as social (culture, economics, politics, etc.), biological (state of the nervous system, chromosomal abnormalities, etc.) and psychological (emotional, volitional, cognitive). Among the psychological factors of aggressiveness, Russian scientists established its relationship:

- With emotional distress, undeveloped empathy and other characteristics of the emotional sphere (Il'in \& Lipina, 2007; Enikolopov, Kuznecova, \& Chudova, 2013; Rean \& Kosheleva, 2019);

- With type of character accentuations, volitional control and arbitrary regulation (Kuznecova \& Rychkova, 2019; Kozlova, Bairova \& Slobodskaja, 2018);

- With locus of control (Voronova, Dubrovina \& Chepurko, 2018) and many other factors (Grigor'eva, Afonina, \& Kabanova, 2018; Jakovlev, Babushkin, Babushkin \&Tarasenko, 2019).

In the study of cognitive factors of aggressiveness, emotional intelligence is currently in the center of research interest (Zsila, Bernath \& Demetrovics, 2015; Strizhnjova, Strekosova \& Zudina, 2018; Shejnov, 2019). These independent studies have established significant negative relationships between indicators of emotional intelligence and aggressiveness: the lower the level of emotional intelligence, the higher the level of aggressiveness. Studies of the relationship of general intelligence with aggressiveness in youth are not known to us. At the same time, the works of Russian and foreign experts show that aggressiveness as a personality trait is formed and manifests itself mainly in the period of early socialization - in childhood and youth (Stattin \& Magnusson, 1989; Kirienko, 2014; Kobzeva, 2006). This determines the need to test the possible relationship of intellectual development with students' aggressiveness in youth.

The theoretical basis of this study is classical approaches to the understanding aggressiveness and hostility as personality traits, due to a combination of psychological factors, and manifested in destructive subjectiveobjective relationships or as a secretive-verbal reaction of negative feelings and assessments. 


\section{RESEARCH METHODOLOGY}

The research was conducted in 2018-2019 in the city of Yoshkar-Ola on the basis of two colleges, included to the professional education system of the Republic of Mari El (Russia). A sample of empirical research was made up of 94 young students: 73 boys and 21 girls aged 15-17.

The method of organizing research is the method of cross sections. The empirical data collection was carried out using the method of "Buss-Durkee Hostility Inventory" (by A.H. Buss and A. Durkee) and "Shortform selection test" (by E.F. Wonderlic, adapted by V.N. Buzin).

The "Buss-Durkee Hostility Inventory" aims to identify forms of aggressive reactions typical of a respondent, such as: physical aggression, indirect aggression, irritability, negativism, resentment, suspicion, verbal aggression, guilt. The data obtained allow us to calculate two indices: aggressiveness as a reaction that is actively manifested "externally", that is, in relation to specific individuals (the sum of the values on the scales of "physical aggression", "irritability", "verbal aggression") and hostility as a negative, distrustful attitude of a person towards others (the sum of the values on the scales of "resentment" and "suspicion").

"Short-form selection test" (by E.F. Wonderlic, adapted by V.N. Buzin) relates to tools for measuring mental abilities and allows evaluating the structure of the personality intelligence and its integral indicator. According to the purpose of the research and considering the difficulty of an objective assessment of the structure of intelligence based on the test, we took into account only the integral indicator of the overall intellectual development of students who took part in this study.

When processing the data to verify the hypothesis, the Spearman rank correlation coefficient was used.

\section{RESULTS}

The results obtained by using the "Buss-Durkee Hostility Inventory" (Figure 1) indicate that our respondents are characterized by high levels of aggressive reactions in 6 out of 8 forms:

- The dominance of a tendency to verbal aggression (89\%) and suspicion (82\%);

- High levels of irritability (78\%) and physical aggression (68\%), although they are expressed to a significantly lesser extent $($ at $p<0.05)$ than the first two forms;

- Negativity and a tendency towards resentment (according to which $59 \%$ and $50 \%$ of students have high levels), as well as a tendency to indirect aggression (52\% with an average level) are even less expressed;

- To a lesser degree (in comparison with all of the above forms), college students expressed guilt ( $43 \%$ with low and $36 \%$ with average levels).

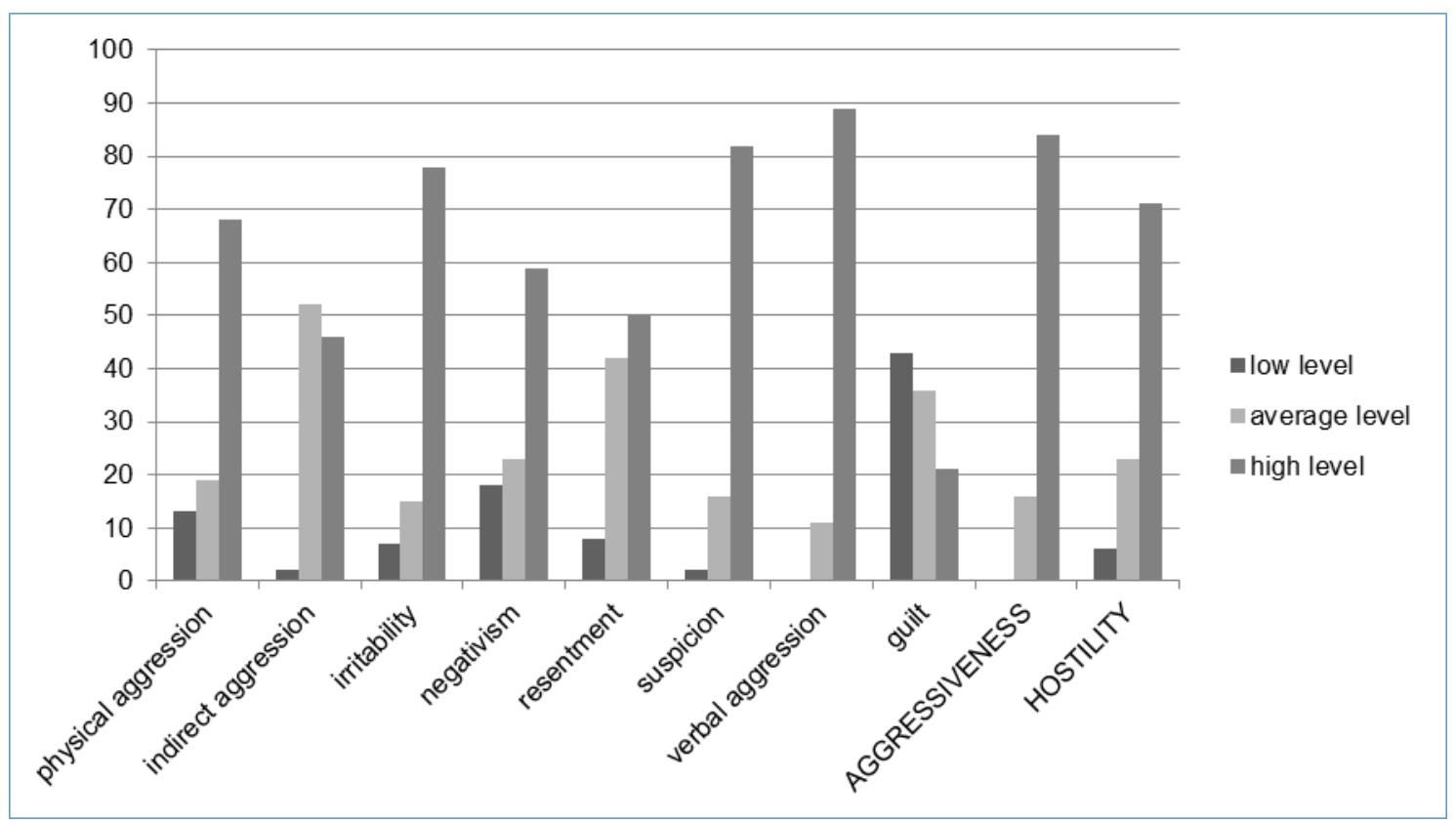

Figure 1. Forms and levels of aggressive reactions, overall aggressiveness and hostility of respondents, \% 
Aggression index, i.e. readiness to show this reaction in relation to others, is characterized by a high level in $84 \%$ of our respondents. Hostility index, i.e. distrust of others, is high among 7 out of 10 respondents (71\%).

According to the "Short-form selection test" results, it was found that $42.6 \%$ of students who took part in the research have a low level of intellectual development (40 people), $24.5 \%$ - below the average level (23 people), the average level was shown by $26.6 \%$ (25 people), and only $6.3 \%$ of respondents are above the average level (6 people). No one showed a high level of intellectual development (Figure 2).

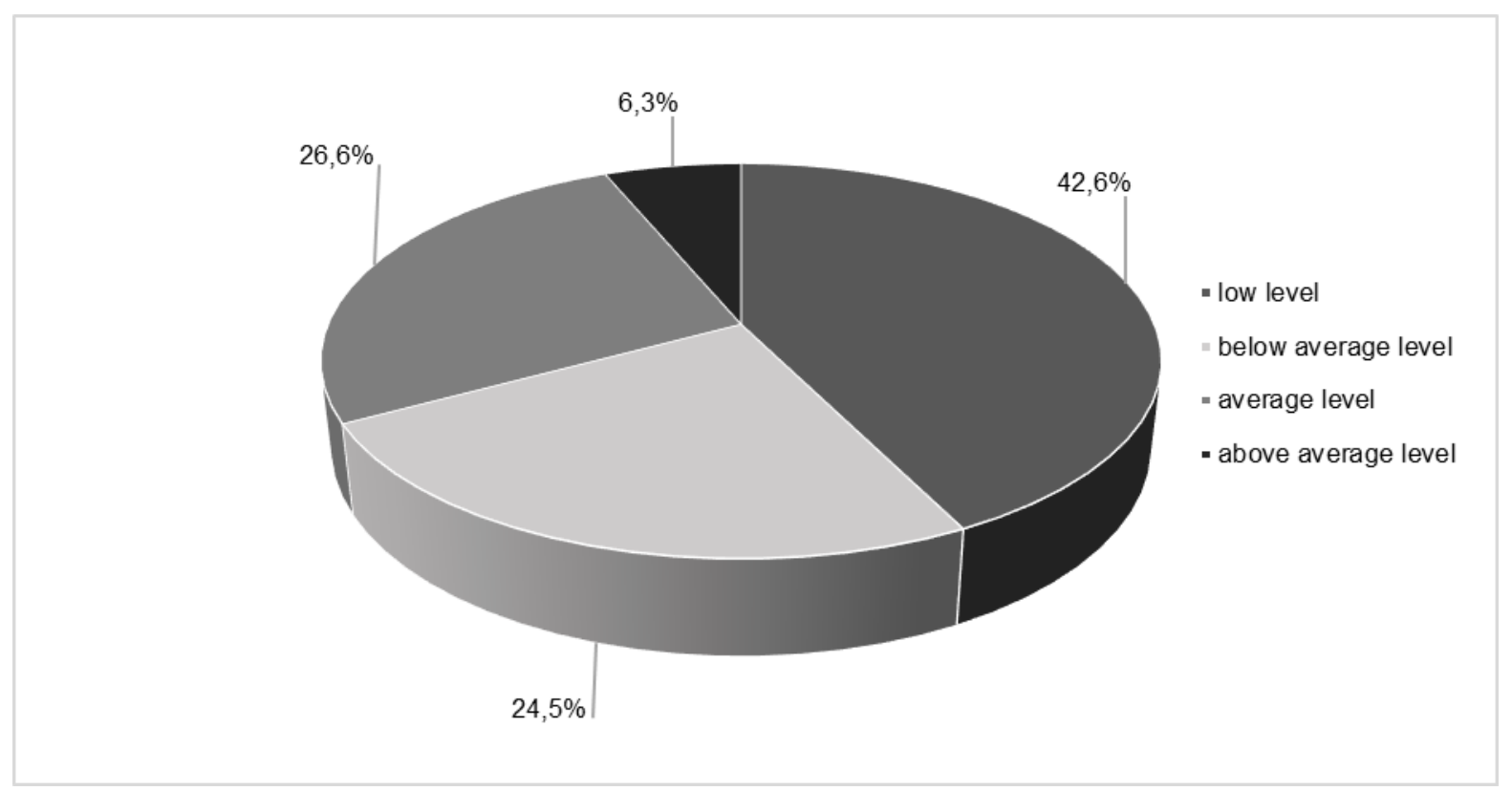

Figure 2. Levels of overall intellectual development of respondents

Only a third of students in professional colleges who participated in an empirical study have average and above average levels of intellectual development.

To test the hypothesis about the relationship of aggressiveness and intellectual development in youth, a correlation analysis was carried out using the Spearman rank correlation method. A statistically significant moderate feedback was established between the integral indicator of the general intellectual development of students and physical aggression (-0.412), i.e. with an increase in the first parameter, the severity of the second decreases. Significant relationships of intelligence with other forms of aggressive reactions, with the level of general aggressiveness and hostility in an empirical sample have not been established.

\section{CONCLUSIONS}

The data obtained during the empirical study allowed us to make the following conclusions:

1. Students of professional colleges in their youth days have high levels of aggressiveness and hostility, which are manifested in a cautious and negative attitude towards others and a readiness to harm other people in response to their actions or to achieve their goal. This can be explained by the specifics of the environment and the student body in professional education institutions (low socio-economic and educational status of students and their families, the popularity of the culture of "violence", etc.).

2. The most common forms of aggressive reactions of students of professional colleges in their youth days are verbal aggression (threat, screaming, cursing) and suspiciousness (distrust, alertness). Most likely, this is a consequence of their assessment of their environment as dangerous and aggressive, which makes us expect malicious intent in others' actions and be always ready to repel possible attacks (irritability or temper, nervousness) and attack ourselves (physical aggression).

3. Two-thirds of students of professional colleges in their youth days have intellectual development below the average level (including 42.6\% - low level), i.e. they have lowered such criteria of intelligence as the ability to analyze and generalize, choose optimal strategies, flexibility of thinking, awareness and others. Obviously, this is a sign and consequence of insufficient quality and the result of both previous education and the current conditions of training.

4. There is an inverse relationship between the level of general intellectual development of students and 
their tendency to physical aggression: the higher the intelligence, the lower the level of physical aggression, and the other way around. It confirms the hypothesis and allows us to conclude that the tendency to physical aggression (skirmishes, brawls, fights, etc.) is more typical for young people with a low level of intellectual development studying in professional colleges. It must be emphasized that the assumption of reduced intelligence is valid only for aggressors of the "brawler" type, since significant relationships with other forms of aggressive behavior in this study have not been established.

\section{ACKNOWLEDGEMENT}

The reported study was funded by RFBR and Government of Mari El Republic according to the research project № 19-413-120006.

\section{REFERENCE LIST}

Allport, G.W. (1960). Personality and social encounter. Boston, MA: Beacon.

Bandura, A. (1983). Psychological mechanisms of aggression. In R.G. Geen \& E.I. Donnerstein (Eds.), Aggression: Theoretical and empirical reviews (1-40). N.-Y.: Academic Press.

Berkowitz, L. (1993). Aggression: Its causes, consequences, and control. N.-Y.: McGraw-Hill.

Buss, A.H. (1961). The psychology of aggression. N.-Y.: Wiley.

Dollard, J., Miller, N. E., Doob, L. W., Mowrer, O. H., \& Sears, R. R. (1939). Frustration and aggression. New Haven, CT, US: Yale University Press.

Freud, S. (1961). Beyond the pleasure principle (J. Strachey, Ed.). New York, NY, US: W W Norton \& Co.

Juvonen, J., \& Graham, S.(2014). Bullying in schools: The power of bullies and the plight of victims. Annual review of psychology, 65, 159-185.

Lorenz, K. (1963). On aggression: Harcourt, Brace and World: New York.

Rogers, C.R. (1995). On becoming a person: a therapist's view of psychotherapy. Boston: Houghton Mifflin.

Salmivalli, C. (2010) Bullying and the peer group: A review. Aggression and violent behavior, 15 (2), $112-$ 120.

Stattin, H., \& Magnusson, D. (1989). The role of early aggressive behavior in the frequency, seriousness, and types of later crime. Journal of Consulting and Clinical Psychology, 57(6), 710-718. DOI: https://doi.org/10.1037/0022-006X.57.6.710

Zsila, Á., Bernath, Á., \& Demetrovics, Z.(2015). Aggression and emotional intelligence: a study on a sample of otaku. Med. psihol. Ross.,4(33),8.

Voronova, T.A., Dubrovina, S.V., \& Chepurko, Ju.V. (2018). Lokus kontrolja kak determinanta agressivnosti pri intellektual'noj odarennosti podrostkov. Obrazovanie i nauka, 20 (8), 28-45.

Grigor'eva, A.A., Afonina, Ju.S., \& Kabanova, T.N. (2018). Kriminalizacija nesovershennoletnih kak problema sovremennogo obshhestva (psihologicheskie, social'no-psihologicheskie i kliniko-psihopatologicheskie faktory). Prikladnaja juridicheskaja psihologija, 4, 49-59.

Gusejnova, E.A., \& Enikolopov, S.N. (2014). Vlijanie pozicii podrostka v bullinge na ego agressivnoe povedenie i samoocenku. Psihologicheskaja nauka i obrazovanie, 6 (2), 246-256.

Enikolopov, S.N., Kuznecova, Ju.M., \& Chudova, N.V. (2013). Agressivnost' i nesposobnost' ponimat' chuzhie jemocii. Psihologicheskaja nauka i obrazovanie, 4, 97-102.

Enikolopov, S.N. (2010) Psihologicheskie problemy bezopasnosti v shkole (stenogramma). Materialy proekta «Obrazovanie, blagopoluchie i razvivajushhajasja jekonomika Rossii, Brazilii i Juzhnoj Afriki». Dostupno: https://psyjournals.ru/edu_economy_wellbeing/issue/36278.shtml

Ivanjushina, V.A., Titkova, V.V., \& Aleksandrov, D.A. (2016). Podrostkovaja agressija: gruppovye normy i social'nyj status sredi sverstnikov. Sociologicheskij zhurnal, 22 (1), 54-71. 
Il'in, E.P., \& Lipina, A.N. (2007). Dinamika harakteristik jemocional'noj sfery i agressivnosti na protjazhenii perioda ot junosti do starosti. Vestnik prakticheskoj psihologii obrazovanija, 4, 42-46.

Il'in, E.P. (2014). Psihologija agressivnogo povedenija. SPb.: Piter.

Kirienko, A.A. (2014). Individual'no-lichnostnye osobennosti agressivnosti podrostkov razlichnyh tipov napravlennosti lichnosti: avtoref. dis. ... kand. psihol. nauk. M.: RUDN.

Kobzeva, O.V. (2006). Dinamika agressivnosti i ee vzaimodejstvija s lichnostnymi osobennostjami v podrostkovom i junosheskom vozrastah: avtoref. dis. ... kand. psihol. nauk. M: PI RAO.

Kozlova, E.A., Bairova, N.B., \& Slobodskaja, E.R. (2018). Reguljatornye sposobnosti v detstve: sovremennye predstavlenija i metody issledovanija. Psihologicheskij zhurnal, 39 (4), 38-48.

Kuznecova, M.N., \& Rychkova, L.S. (2019) Vzaimosvjaz' lichnostnyh harakteristik i predraspolozhennosti k destruktivnomu povedeniju u podrostkov. Uchenye zapiski universiteta im. P.F. Lesgafta, 5 (171), 432435.

Nalchadzhan, A.A. (2007). Agressivnost' cheloveka. SPb: Piter.

Rean, A.A. (1996). Agressija i agressivnost' lichnosti. Psihologicheskij zhurnal, 5, 3-18.

Rean, A.A., \& Kosheleva, E.S. (2019). Agressivnost' kak prediktor deficita oshhushhenija schast'ja u podrostkov. Vestnik Moskovskogo universiteta MVD Rossii, 3, 258-263.

Rossijskie shkol'niki stali chashhe projavljat' agressiju (2018). Kommersant, 58, 5.

Safonov, V.K. (2003). Agressija v sporte. SPb.: Izd-vo S.-Peterb. un-ta.

Semenjuk, L.M. (1996). Psihologicheskie osobennosti agressivnogo povedenija podrostka i uslovija ego korrekcii. Moskva-Voronezh: MPSI: MODJeK.

Sen'ko, T.V. (2002). Psihologija vzaimodejstvija: chast'. 4. Istoki agressivnogo povedenija detej. Minsk: Karandashev.

Cejchas vzorvus'. Psihologi narisovali portret sovremennogo rossijanina (2013). Rossijskaja gazeta, 6254, 11.

Sluchai napadenij v rossijskih shkolah v 2017-2018 godah (2018). Dos'e. Dostupno: URL: https://tass.ru/info/4885783.

Strizhnjova, L.V., Strekosova, V.S., \& Zudina, N.F. (2018). Svjaz' jempatii s jemocional'nym intellektom i agressivnost'ju u uchashhihsja chetvertyh klassov. Iz (sost. Sitnikov), Sem'ja i deti v sovremennom mire (525-526). Sankt-Peterburg: RGPU im. A.I. Gercena.

Furmanov, I.A. (1996). Detskaja agressivnost'. Minsk: Il'in V.P.

Shejnov, V.P. (2019). Vzaimosvjazi viktimizacii i jemocional'nogo intellekta: polovozrastnye osobennosti. Vestnik Rossijskogo universiteta druzhby narodov. Serija: Psihologija i pedagogika, 16 (3), 377-392.

Jakovlev, B.P., Babushkin, G.D., Babushkin, E.G., \& Tarasenko, I.B. (2019). Psihologo-pedagogicheskie faktory vozniknovenija deviacij $v$ povedenii sovremennyh podrostkov. Psihopedagogika $v$ pravoohranitel'nyh organah, 24 (1), 68-73. 